\title{
A hygienic intervention program to decrease post-operative wound infections following CABG
}

\author{
B Lytsy ${ }^{1 *}$, RPF Lindblom², U Ransjö ${ }^{1}, C L$ Swenne ${ }^{3}$ \\ From 3rd International Conference on Prevention and Infection Control (ICPIC 2015) \\ Geneva, Switzerland. 16-19 June 2015
}

\section{Introduction}

The department of Cardiothoracic surgery at Uppsala University Hospital has 25 beds in 1-4 patient rooms and an operating suite consisting of 5 operating rooms with ultraclean air. Around 700 open heart (250 isolated Coronary artery by-pass grafting, CABG) operations are performed annually. In 2009, the numbers of deep sternal wound infections (DSWI) increased to unacceptable rates despite existing hygienic guidelines.

\section{Objectives}

To show how root cause analysis followed by quality improvement interventions reduced the rate of DSWI after CABG surgery.

\section{Methods}

Only isolated CABG patients requiring surgical revision due to DSWI were included.Swabs and tissue biopsies were taken during surgical revision and analysed with standard methods. DSWI were registered prospectively according to CDC definitions. A root cause analysis for infection was performed Sep 2009-April 2010. Interventions based on results of the root cause analysis and on nationally recommended practices were concluded in April 2010, and thought to have taken full effect by July 1,2010 . Air was actively sampled at $\leq 0.5 \mathrm{~m}$ from the sternal incision.

\section{Results}

DSSI incidence rates per CABG operations decreased from $5.1 \%$ pre- to $0.9 \%$ post- intervention. Wound cultures pre-intervention grew S. aureus $27.1 \%$ and CoNS $47.1 \%$, post-intervention S. aureus $23.1 \%$ and CoNS $30.8 \%$. Air counts did not exceed $5 \mathrm{cfu} / \mathrm{m}^{3}$.

${ }^{1}$ Department of Clinical Microbiology and Infection Control, Uppsala University, Uppsala, Sweden

Full list of author information is available at the end of the article

\section{Conclusion}

Good facilities and ventilation in the operating room cannot guarantee low infection rates. Guidelines are necessary, but strong leadership among all professions is needed to ensure compliance to guidelines.

\section{Disclosure of interest}

None declared.

\section{Authors' details}

${ }^{1}$ Department of Clinical Microbiology and Infection Control, Uppsala University, Uppsala, Sweden. ${ }^{2}$ Department of Thoracic Surgery and Anesthesiology, Uppsala University Hospital, Uppsala University, Uppsala, Sweden. ${ }^{3}$ Department of Public Health and Caring Sciences, Uppsala University, Uppsala, Sweden.

Published: 16 June 2015

doi:10.1186/2047-2994-4-S1-032

Cite this article as: Lytsy et al:: A hygienic intervention program to decrease post-operative wound infections following CABG. Antimicrobial Resistance and Infection Control 2015 4(Suppl 1):O32.

Submit your next manuscript to BioMed Central and take full advantage of:

- Convenient online submission

- Thorough peer review

- No space constraints or color figure charges

- Immediate publication on acceptance

- Inclusion in PubMed, CAS, Scopus and Google Scholar

- Research which is freely available for redistribution 